\title{
THE
}

\section{Flight without Horizon References in European Starlings}

Robert G. Moyle

Frank H. Heppner

University of Rhode Island

Follow this and additional works at: https://digitalcommons.uri.edu/bio_facpubs

Terms of Use

All rights reserved under copyright.

\section{Citation/Publisher Attribution}

Moyle, R., \& Heppner, F. (1998). Flight without Horizon References in European Starlings. The Auk, 115(3), 771-774. doi:10.2307/4089427

Available at: http://dx.doi.org/10.2307/4089427

This Article is brought to you for free and open access by the Biological Sciences at DigitalCommons@URI. It has been accepted for inclusion in Biological Sciences Faculty Publications by an authorized administrator of DigitalCommons@URI.For more information, please contact digitalcommons-group@uri.edu. 
Flight without Horizon References in European Starlings

Author(s): Robert G. Moyle and Frank H. Heppner

Source: The Auk, Vol. 115, No. 3 (Jul., 1998), pp. 771-774

Published by: American Ornithological Society

Stable URL: https://www.jstor.org/stable/4089427

Accessed: 30-08-2018 16:53 UTC

\section{REFERENCES}

Linked references are available on JSTOR for this article:

https://www.jstor.org/stable/4089427?seq=1\&cid=pdf-reference\#references_tab_contents You may need to log in to JSTOR to access the linked references.

JSTOR is a not-for-profit service that helps scholars, researchers, and students discover, use, and build upon a wide range of content in a trusted digital archive. We use information technology and tools to increase productivity and facilitate new forms of scholarship. For more information about JSTOR, please contact support@jstor.org.

Your use of the JSTOR archive indicates your acceptance of the Terms \& Conditions of Use, available at https://about.jstor.org/terms

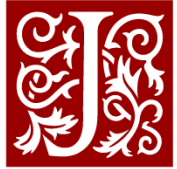

American Ornithological Society is collaborating with JSTOR to digitize, preserve and extend access to The Auk 
Voous, K. H. 1950. The breeding cycles of birds in Indonesia. Ibis 92:279-316.

WEIMERSKIRCH, H., J. C. STAHL, AND P. JOUVENTIN. 1992. The breeding biology and population dynamics of King Penguins Aptenodytes patagonica on the Crozet Islands. Ibis 134:107-117.
Williams, T. D. 1995. The penguins. Oxford University Press, Oxford.

Received 16 January 1997, accepted 13 November 1997. Associate Editor: J. M. Eadie

The Auk 115(3):771-774, 1998

\title{
Flight Without Horizon References in European Starlings
}

\author{
Robert G. MOYLE ${ }^{1}$ AND Frank H. HePpNeR \\ Department of Biological Sciences, University of Rhode Island, Kingston, Rhode Island 02881, USA
}

Many birds fly at night, or in conditions in which a horizon reference is obscured or missing (Berthold 1993). Nonmigratory species such as European Starlings (Sturnus vulgaris) will fly near their roosts in large flocks long after the sun has set (Eastwood 1967). Nocturnal migration and flocking after dusk occur under a variety of meteorological conditions, including fog and heavy cloud cover (Evans 1972, Elkins 1983). These behaviors suggest that for some bird species, visual references are not always necessary to maintain straight and level flight.

Radar studies (Griffin 1972) suggest that some birds can maintain straight and level flight under completely overcast conditions, but birds flying within clouds may produce erratic tracks, suggesting disorientation in the absence of visual cues. Able (1982) used a tracking radar to examine the behavior of nocturnal migrants under overcast conditions and concluded that overcast skies did not result in changes in flight behavior. However, he acknowledged that some degree of disorientation occurred when birds seemed to be flying within or between cloud layers.

Williams and Teal (1973) blindfolded individuals of six species of birds (Song Sparrow [Melospiza melodia], White-throated Sparrow [Zonotrichia albicollis], Dark-eyed Junco [Junco hyemalis], House Sparrow [Passer domesticus], Rock Dove [Columba livia], and Herring Gull [Larus argentatus]) to observe their flight in the absence of visual cues. One out of every six birds tested tried to fly upside down and crashed, and one-third of the birds dropped immediately to the ground, often using fluttering flight. Only Her-

\footnotetext{
${ }^{1}$ Present address: Museum of Natural Science, 119 Foster Hall, Louisiana State University, Baton Rouge, Louisiana 70803, USA.

E-mail: rmoyle@unix1.sncc.lsu.edu
}

ring Gulls seemed to be little affected by the blindfolds, and 10 gulls exhibited normal flight. However, 2 of the 13 gulls used in the experiment would not fly and had difficulty standing upright.

Two types of orientation might be affected if visual cues are removed from a flying bird. The first is primary orientation, which concerns the positioning of the organism in three-dimensional space with reference to a constant direction, such as the gravitational pull of the earth. Superimposed upon this primary orientation is secondary orientation, which relates to the organism's ability to maintain a directional heading across the earth (Fraenkel and Gunn 1940). A bird deprived of visual cues might find it difficult to maintain a compass heading or heading toward the roost, but it might also experience a breakdown of primary orientation and be unable to maintain straight and level flight.

Primary or positional orientation has been studied relatively little, especially with respect to flying organisms, although several authors have speculated on possible mechanisms (Delius and Vollrath 1973, Jander 1975, Schöne 1984). Slanted banks of clouds can cause a human pilot to unknowingly fly in a bank (Bending 1959, Gillingham and Wolfe 1986). If no visual horizon reference is available and the pilot is flying without instrumentation, the ability to keep the plane straight and level will be lost almost immediately, and a total loss of control and downward spiral or spin to the ground usually are the result (Spector 1967).

Methods.-We used a wind tunnel to examine the flight behavior of European Starlings under four different lighting conditions, ranging from normal indoor lighting to darkness. The flight area of the tunnel measured $0.91 \mathrm{~m}$ (length) $\times 0.58 \mathrm{~m}$ (height) $\times$ $0.58 \mathrm{~m}$ (width). The front of the flight area was a honeycomb mesh and the back was wire screen. The top, bottom, and both sides were constructed of clear 
Plexiglas. Rayner (1994) summarized previous windtunnel studies and described how free flight may differ from that in a closed-section wind tunnel.

Wild-caught starlings that had been in captivity for six months were flown in the tunnel four times a week with full room lighting to acclimate them to the tunnel. The only incentive given to the birds during this period was a cage of conspecifics placed on top of the front portion of the tunnel. After six weeks, birds that consistently flew for more than one minute were selected for study. Most of the test subjects flew for $10 \mathrm{~min}$ or more, but occasionally they landed for no obvious reason.

Wind speed in the flight chamber ranged from 12.5 to $14 \mathrm{~m} \mathrm{~s}^{-1}$ for all trials. Turbulence in the flight chamber of the tunnel was measured at 3 to $5 \%$ using a hot-wire anemometer (Biewener et al. 1992). Each trial lasted for $60 \mathrm{~s}$. Test birds were hand-released into the flight chamber between 0 and $5 \mathrm{~s}$; between 10 and $15 \mathrm{~s}$, any lighting changes that were due to occur in that trial were implemented. Lighting conditions remained constant from $15 \mathrm{~s}$ until the end of the trial at $60 \mathrm{~s}$. At $60 \mathrm{~s}$, any lighting changes were reversed, and the bird was extracted from the wind tunnel, even if it was still in flight.

Light for the experimental trials was provided by a single 120-volt photographic flood lamp aimed at the ceiling and measured with a Gossen Luna-Pro incident light meter. This produced 1,400 lux in the flight chamber, approximately the same as provided by fluorescent ceiling lights. The flood lamp provided moderate but diffuse lighting in the entire windtunnel laboratory. The front and back screens of the flight chamber were easily visible, as were all details in the laboratory. We tested birds under four light regimes: (1) "light," (2) "dim," (3) "dark," and (4) "reference."

Light levels under the "light" regime were 1,400 lux and remained constant throughout the trial. These trials should indicate the flight ability and behavior in the wind tunnel with no adverse lighting conditions. In the "dim" regime, the flood lamp was gradually dimmed from 1,400 lux at $10 \mathrm{~s}$ to $1.2 \mathrm{lux}$ by $15 \mathrm{~s}$. This provided diffuse and very dim light in the laboratory. When illuminated in this manner, the front and back ends of the flight chamber could be distinguished by a human observer to be darker than the walls. In the laboratory, shapes could be distinguished but no details. These trials were performed to determine if any change in flight ability, willingness, or behavior was caused by a gradual change in light level rather than the resultant light level alone. In the "dark" regime, the flood lamp was gradually extinguished between 10 and $15 \mathrm{~s}$ of each trial. To block any extraneous light, black electrical tape and tar paper were used to cover all light sources in the room. Under these circumstances, less than 0.085 lux (the limit of the light meter's sensitivity) occurred in the flight chamber, and no light or shapes were vis- ible to a human observer who had been acclimated in the room for two minutes. Trials under the "reference" regime were exactly the same as those described for "dark" except that a luminescent strip $0.58 \mathrm{~m}$ long $\times 4 \mathrm{~mm}$ wide was placed across the wind tunnel midway up the front screen. The luminescent strip consisted of a length of adhesive luminescent material cut from an "exit" sign. The material was attached to a thin metal strip $4 \mathrm{~mm}$ wide. The metal strip was fastened to the front screen of the flight area. A $12-\mathrm{cm}$ piece of the material was also placed at the same level at the front end of each side wall of the flight chamber. The luminescent material recharged when exposed to light, and in complete darkness it remained visible to a human observer for more than $2 \mathrm{~min}$. The strips were visible but were not bright enough to illuminate anything else and provided a horizon reference inside the tunnel.

All of the trials were videotaped with an infraredsensitive (IR) video camera (Panasonic WV-CD20). Light for the IR camera was provided by a $250-\mathrm{W}$ General Electric heat bulb enclosed in a light-tight steel case that had one port covered with an RM-86 filter. A dim red glow was visible with this filter in place, so a military surplus IR filter was added to the RM-86 filter. No visible light emanated from the port when both filters were in place.

From the videotapes of the trials, we determined the time from introduction into the tunnel until each bird first landed, as well as the total time in flight. Total time of flight included any secondary flights after the initial landing. The number of times each bird took off during each trial was also recorded. Finally, the method of each landing was characterized as: (1) a controlled landing; (2) a crash; or (3) a landing caused by the bird drifting into one of the walls, but with no evidence of a loss of primary orientation. A crash was defined as loss of controlled flight not caused by contact with any of the surfaces of the wind tunnel. These resulted in the bird being quickly swept to the rear of the tunnel and appeared to cause the bird no harm. Thus, if a bird landed due to drifting into the front screen after $20 \mathrm{~s}$ and then took off again $10 \mathrm{~s}$ later and remained in flight for the remainder of the trial, the data would be recorded as $20 \mathrm{~s}$ to first landing, $50 \mathrm{~s}$ total flight time, one "drift," and one reflight.

We used one-way repeated-measures ANOVA to test for differences in mean total flight time among lighting regimes. When significant differences were found among treatments, we used a Student-Newman-Keuls test to isolate the groups that differed from the others.

Results and discussion.-Flight in the wind tunnel appeared normal under "light" conditions, alternating between flapping and short glides. Starlings tucked their feet up against their bodies unless a landing was imminent. In the "dark" and "reference" trials, every bird lowered its legs during flight. 
TABLE 1. Time to first alighting $(\bar{x} \pm S E)$; total flight time $(\bar{x} \pm S E)$; and total number of reflights, landings, drifts, and crashes in 12 European Starlings. Means of total flight time with different letter in superscript are significantly different $(P<0.05$; Student-Newman-Keuls test).

\begin{tabular}{|c|c|c|c|c|c|c|}
\hline $\begin{array}{l}\text { Light } \\
\text { regime }\end{array}$ & $\begin{array}{l}\text { Time to first } \\
\text { alighting }(s)^{\text {a }}\end{array}$ & $\begin{array}{l}\text { Total flight } \\
\text { time (s) }\end{array}$ & Reflight & Land & Drift & Crash \\
\hline Light & $47.5 \pm 9.50(2)$ & $57.9 \pm 1.83^{\mathrm{A}}$ & 0 & 1 & 1 & 0 \\
\hline Dim & $29.8 \pm 9.03(4)$ & $50.8 \pm 4.65^{\mathrm{A}}$ & 1 & 3 & 1 & 0 \\
\hline Dark & $22.5 \pm 2.10(12)$ & $22.5 \pm 2.10^{\mathrm{B}}$ & 0 & 5 & 6 & 1 \\
\hline Reference & $25.3 \pm 2.35(12)$ & $27.8 \pm 2.47^{\mathrm{B}}$ & 5 & 10 & 6 & 1 \\
\hline
\end{tabular}

a Numbers in parentheses indicate the number of birds that landed in some manner in that light regime. Some birds flew for the duration of a trial and are not included in time to first alighting.

Flapping and gliding were replaced with constant, rapid flapping.

With respect to flight duration, our data suggest that although European Starlings have some ability to maintain straight and level flight in the absence of visual cues, they appear to be more reluctant to fly under conditions of low visibility than when visual cues are available (Table 1 ). Ten of the 12 birds were still flying after one minute in the "light" condition, whereas all birds landed before one minute in the "dark" condition. However, in the "dark" condition, birds did fly after the lighting change was made, and most landings were either controlled or caused by drifting into a wall of the wind tunnel (Table 1). The light changes were only completed at $15 \mathrm{~s}$, so the mean flight time in the dark was only slightly more than $7 \mathrm{~s}$. The longest flight in the "dark" was $36 \mathrm{~s}$ (21 $s$ in complete darkness).

The increase in controlled landings suggests that starlings were unwilling to fly in the dark. The true extent of flight without visual cues was not seen because the birds that continued to fly in the "dark" conditions either landed under control or were limited by the confines of the flight tunnel and drifted into walls that they could no longer see. The change in light levels also seemed to influence the birds' willingness to fly. In the "dim" trials, two birds landed within two seconds of the light change. Twothirds of the "dim" trials resulted in the bird flying for the duration of the trial, and one of the birds that landed just after the light change later resumed flight. This suggests that low light level per se did not interfere with flight ability, but that the changing of the light level may have been a factor.

The biggest change in flight behavior between the "dark" and "reference" trials was the number of reflights. Although no reflights occurred in total darkness, five occurred when a horizon line was present. The increased number of takeoffs resulted in an increased number of total landings, but all of the extra landings were controlled (i.e. not drifts or crashes).

These data do not indicate that there is a minimum amount of time without visual cues necessary to cause a loss of primary orientation in European Starlings. The one crash that took place in the "dark" condition occurred after $5 \mathrm{~s}$ in the dark $(20 \mathrm{~s}$ total time). However, another bird was able to fly for $21 \mathrm{~s}$ in the dark and then make a controlled landing.

The starlings in our study responded in two general ways to the loss of horizon references. The first was a reluctance to fly under these conditions. The second was an increase in the rate of flapping and a lowering of the feet during flight. Dropping the feet would lower the bird's center of gravity, providing greater stability. However, the change in aerodynamics and the increase in flapping rate would decrease energetic efficiency. The reluctance to fly and the change in flight mechanics may affect the timing of roosting and the foraging range when low clouds and fog reduce visibility.

The possibility of primary disorientation at night and / or in clouds is likely to function as a constraint on the timing of roosting and the amount of flocking after dusk in European Starlings. Although starlings appear to have some ability to fly with no visual cues, they are hesitant to do so. This may affect the birds' decision-making process in initiating flight under conditions in which the horizon or other visual cues might be obscured.

The birds used in our study are not migratory. It is possible that nocturnal migrants are better able to maintain primary orientation than are nonmigrants. However, if a nocturnal migrant responds to the loss of horizon references in a manner similar to that displayed by the starlings, the timing and path of migration could be affected.

Acknowledgments.-We are indebted to G. E. Goslow for the use of his wind tunnel and J. S. Cobb for all of the IR equipment. F. H. Sheldon, T. Williams, B. Tobalske, and an anonymous reviewer made helpful comments on the manuscript.

\section{Literature Cited}

ABLE, K. P. 1982. The effects of overcast skies on the orientation of free-flying nocturnal migrants. Pages 38-49 in Avian navigation (F. Papi and H. G. Wallraff, Eds.). Springer-Verlag, Berlin.

BENDING, G. C. 1959. Spatial disorientation in jet aircrews. Journal of Aviation Medicine 30:107-112. 
BERTHOLD, P. 1993. Bird migration: A general survey. Oxford University Press, Oxford.

Biewener, A. A., K. P. Dial, AND G. E. Goslow. 1992. Pectoralis muscle force and power output during flight in the starling. Journal of Experimental Biology 164:1-18.

DeliUS, J. D., AND F. W. VOlLRATH. 1973. Rotational compensation reflexes independent of the labyrinth. Journal of Comparative Physiology 83: 123-134.

EASTwOOD, E. 1967. Radar ornithology. Methuen and Company, London.

ELKINS, N. 1983. Weather and bird behavior. T. and A. D. Poyser, Staffordshire, United Kingdom.

EVANS, P. R. 1972. Information on bird navigation obtained by British long-range radars. Pages 139149 in Animal orientation and navigation: A symposium. NASA SP-262. United States Government Printing Office, Washington, D.C.

FraENKEL, G. S., AND D. L. GUNN. 1940. The orientation of animals: Kinesis, taxes and compass reactions. Dover Publications, New York.

GillinghaM, K. K., AND J. W. WOLfE. 1986. Spatial orientation in flight. United States Air Force School of Aerospace Medicine, Brooks AFB, Texas.

GRIFFIN, D. R. 1972. Nocturnal bird migration in opaque clouds. Pages 169-188 in Animal orientation and navigation: A symposium. NASA SP262. United States Government Printing Office, Washington, D.C.

JANDER, R. 1975. Ecological aspects of spatial orientation. Annual Review of Ecology and Systematics 6:171-188.

RAYNER, J. M. V. 1994. Aerodynamic corrections for the flight of birds and bats in wind tunnels. Journal of Zoology (London) 234:537-563.

SCHÖNE, H. 1984. Spatial orientation. Princeton University Press, Princeton, New Jersey.

SPECTOR, M. 1967. Dizziness and vertigo. Grune and Stratton, New York.

Williams, T. C., AND J. M. TEAL. 1973. The flight of blindfolded birds. Bird-Banding 44:102-109.

Received 1 May 1997, accepted 3 December 1997.

Associate Editor: R. M. Zink

The Auk 115(3):774-780, 1998

\title{
Molt Patterns of Nonbreeding White-faced Whistling-Ducks in South Africa
}

\author{
SCOTT A. PETRIE ${ }^{1}$ \\ Center for Water in the Environment, University of the Witwatersrand, Johannesburg, South Africa
}

The tribe Dendrocygnini (whistling-ducks) contains nine species that have a circumequatorial distribution (Bolen and Rylander 1983). Whistlingducks are distinct from most other ducks in that they are perennially monogamous, share incubation and brood-rearing duties, and retain the ancestral pattern of replacing their contour feathers only once per annual cycle. The chronology of molt in whistlingducks and the timing and location of remigial replacement are poorly understood, and whistlingducks are one of the least-studied tribes of waterfowl in the world (Hohman et. al 1992, Hohman and Richard 1994, Petrie 1998).

The White-faced Whistling-Duck (Dendrocygna viduata) is widespread in the Afrotropical and Neotropical regions and in most of the semiarid regions

${ }^{1}$ Present address: Long Point Waterfowl and Wetlands Research Fund, c/o Bird Studies Canada, P.O. Box 160, Port Rowan, Ontario NOE 1M0, Canada. E-mail: spetrie@bsc-eoc.org of sub-Saharan Africa (Madge and Burn 1988). When they arrive on breeding areas in interior South Africa, White-faced Whistling-Ducks are molting in most feather tracts (Petrie 1998). Both sexes continue to molt during the period of early rapid follicle growth in females, suspend molt (or nearly so) during laying and incubation, and resume molt during the brood-rearing period. However, it is unknown if White-faced Whistling-Ducks continue this single annual molt throughout the winter and spring.

I investigated the intensity and chronology of molt in nonbreeding White-faced Whistling-Ducks in South Africa. My goal was to determine whether they replace their remiges on the wintering grounds and to evaluate their molt relative to environmental and phylogenetic constraints. Because the diet of White-faced Whistling-Ducks is relatively deficient in protein (Petrie and Rogers 1996, Petrie 1998), and prolonged low-intensity feather replacement reduces daily nutrient requirements of molt (Blackmore 1969, Payne 1972), I hypothesized that these ducks prolong the replacement of their contour feathers 